\title{
REVIEW
}

\section{Environmental issues of fish farming in offshore waters: perspectives, concerns and research needs}

\author{
Marianne Holmer* \\ Institute of Biology, University of Southern Denmark, Campusvej 55, DK-5230 Odense M, Denmark
}

\begin{abstract}
Offshore fish farming is predicted to increase in the near future driven by the lack of coastal space. In this review I discuss the environmental issues of offshore farming from experience in coastal farms. Even more so than in coastal farms, a rapid and wide dispersal of dissolved waste products is predicted for offshore farms. Despite wider dispersal of particulate waste products, fast sinking rates of feed pellets and faeces suggest organic enrichment of the bottom sediments in farm vicinities (hundreds of meters), although at lower loading rates than coastal farms. The benthic response to organic enrichment is unpredictable due to lack of knowledge from shelf areas. Most shelf sediments are considered carbon limited and fish farm waste products may stimulate the benthic communities, but due to the sparse abundance and absence of pollutant-tolerant benthic fauna, the capacity of benthic communities to assimilate organic matter may be limited. Instead, microbial decomposition of waste products could become important, leading to increased oxygen demand and accumulation of sulfides in the sediments. This may negatively affect benthic biodiversity. Interactions with wild fish (aggregation, genetic impacts, spreading of disease and parasites) are expected, but difficult to predict, as the composition of species attracted to offshore farms will be different from that of species attracted to coastal farms. Escapees are potentially a high risk due to farm failure under rough weather conditions in the open sea. The carbon footprint of farming offshore will increase (transportation) and the ecological footprint (fishing feed) will remain a severe constraint, as in coastal farming. Offshore farming is subject to high costs of operation, including those for monitoring environmental conditions. Research should focus on interactions with wild fish populations, mapping of sensitive benthic habitats and experimental studies of the response of benthic habitats to organic enrichments.
\end{abstract}

KEY WORDS: Mariculture $\cdot$ Environment $\cdot$ Sediments $\cdot$ Benthic fauna $\cdot$ Wild fish $\cdot$ Nutrients

\section{INTRODUCTION}

Aquaculture has the potential to play a major role in feeding the human population in the future (Duarte et al. 2009). Catches from fisheries are unlikely to increase and terrestrial food production is limited by the availability of freshwater and arable land, creating a ceiling to global food production. Mariculture, on the other hand, has little demand for freshwater and the demand for space is not an immediate limiting factor, as $70 \%$ of the surface of Earth is covered by ocean. To accomplish the demands of the 9 billion inhabitants predicted for 2050 , less than $4 \%$ of the continental shelf area is required for mariculture production (Duarte et al. 2009). There are, however, numerous problems to reach this level of production, including the availability of suitable production locations. Mariculture is currently concentrated in a few highly productive countries (e.g. China, Norway, Chile), where sheltered coastal locations already are limiting. Over the last decade, farming in Norway has, as an example, moved from sheltered fjords to coastal and more exposed sites in search of new production sites. Further, the collapse in salmon farming in Chile has been forecasted as a motivation factor to move farms further out to sea. Uncontrolled and rapid spread of infectious salmon anaemia in the intensively farmed Chiloe Sea was the main reason for the collapse of the Chilean industry in 2008-2009, leading to an economic loss exceeding the total earnings since farming started in 
Chile (Vike et al. 2009). Other countries like Spain, Ireland and the USA do not have sheltered fjords and are developing aquaculture under offshore conditions (e.g. Toledo-Guedes et al. 2009). Moreover, environmental issues are considered an important driving force for offshore farming, as the pressure on and from the environment is expected to be less at offshore sites due to larger dispersal of waste products and fewer interactions with coastal flora and fauna.

Knowledge of the environmental issues in offshore farming is limited, but moving offshore is considered advantageous both to the fish and the environment. Fish welfare in offshore farms is expected to improve due to higher water quality with less influence from terrestrial run-off and coastal activities, and waste products from farming are rapidly diluted, reducing the local environmental effects and increasing the carrying capacity of the farming sites. At present, the documentation of environmental effects at offshore farms is limited due to the relatively few full-scale offshore farms under operation. Furthermore, predictions of environmental effects are constrained by limited scientific knowledge from the shelf area, and there is a risk of misconception by a direct transfer of experience from coastal zones to offshore conditions. The following review describes areas of environmental concern in offshore mariculture based on observations in coastal farms. Also, this review aims at identifying knowledge gaps on the road to an environmentally sustainable 'blue revolution' in offshore locations.

\section{DEFINITIONS AND SETTINGS}

The concepts of offshore farming are globally diverse with no established definitions. A variety of terms are used in the literature and contribute to the incon- sistency in interpretation of issues related to offshore farming and, eventually, to confusion and conflicts in developing and regulating the sector. A working group addressing offshore aquaculture has provided a set of guidelines to distinguish between coastal, off-coast and offshore farming with the aim of establishing common terminology for general use (Y. Olsen et al. unpubl. data). The distinction between coastal and off-coast farming is primarily based on the distance to the coast: coastal farms are located less than $500 \mathrm{~m}$ from the coast in contrast to up to $3 \mathrm{~km}$ from shore for off-coast farms (Table 1). Coastal farms are located in shallow water depths $(<10 \mathrm{~m})$, resulting in direct coupling between water column processes and the benthic environment, as well as visual impact of farming to coastal users. Offcoast farming occurs at depths between 10 and $50 \mathrm{~m}$, but farms are often within sight and somewhat sheltered, leading to some benthic and visual impacts. Offshore farms are, compared to off-coast farms, more exposed and subject to ocean swells, strong winds and strong ocean currents with significant wave heights of up to 3 to $4 \mathrm{~m}$. The farms are located at water depths $>50 \mathrm{~m}$ and several $\mathrm{km}$ from shore, minimizing both benthic and visual impacts. These 3 classifications of farming will be used in this review, although there are unresolved questions concerning policy issues and legal terms (locations of farms in relation to the baseline of the coast, location in the Exclusive Economic Zone [EEZ], territorial waters, etc.), which could potentially affect the development and regulation of the sector. One recent example is from the USA, where Congress is proposing a ban of aquaculture in the EEZ, which would prohibit development of offshore farming in the USA. The term open-ocean aquaculture has been used to some extent in previous literature, and is included either in the off-coast and offshore definitions based on the description provided in the specific reference.

Table 1. Definitions and examples of major producer countries of coastal, off-coast and offshore farming based on some physical and hydrodynamical settings. Accessibility $<100 \%$ refers to limitations in access to the farm due to weather conditions

\begin{tabular}{|c|c|c|c|}
\hline & Coastal farming & Off-coast farming & Offshore farming \\
\hline Physical setting & $\begin{array}{l}<500 \mathrm{~m} \text { from shore } \\
<10 \mathrm{~m} \text { water depth } \\
\text { Within sight of shore } \\
\text { users }\end{array}$ & $\begin{array}{l}500 \mathrm{~m} \text { to } 3 \mathrm{~km} \text { from shore } \\
10 \text { to } 50 \mathrm{~m} \text { water depth } \\
\text { Usually within sight }\end{array}$ & $\begin{array}{l}>3 \mathrm{~km} \text { from shore } \\
>50 \mathrm{~m} \text { water depth } \\
\text { On continental shelf } \\
\text { Not visible from shore }\end{array}$ \\
\hline Exposure & $\begin{array}{l}\text { Waves }<1 \mathrm{~m} \\
\text { Local winds } \\
\text { Local currents } \\
\text { Strong tidal currents } \\
\text { Sheltered } \\
100 \% \text { accessibility }\end{array}$ & $\begin{array}{l}\text { Waves }<3 \text { to } 4 \mathrm{~m} \\
\text { Localized winds } \\
\text { Localized currents } \\
\text { Weak tidal currents } \\
\text { Somewhat sheltered } \\
>90 \% \text { accessibility }\end{array}$ & $\begin{array}{l}\text { Waves up to } 5 \mathrm{~m} \\
\text { Ocean winds } \\
\text { Ocean swell } \\
\text { No tidal currents } \\
\text { Exposed } \\
>80 \% \text { accessibility }\end{array}$ \\
\hline Legal definitions & $\begin{array}{l}\text { Within coastal baseline } \\
\text { National waters }\end{array}$ & $\begin{array}{l}\text { Within coastal baseline } \\
\text { National waters }\end{array}$ & $\begin{array}{l}\text { Outside coastal baseline } \\
\text { National/international waters }\end{array}$ \\
\hline Examples of major producers & $\begin{array}{l}\text { China } \\
\text { Chile } \\
\text { Norway }\end{array}$ & $\begin{array}{l}\text { Chile } \\
\text { Norway } \\
\text { Mediterranean }\end{array}$ & $\begin{array}{l}\text { USA (Hawaii) } \\
\text { Spain (Canaries) }\end{array}$ \\
\hline
\end{tabular}


Whereas the size of offshore farms is predicted to increase for economic reasons beyond the largest off-coast farming operations at the moment $\left(>10000 \mathrm{t} \mathrm{yr}^{-1}\right)$, the production principles are similar to modern coastal farming. Fish are cultured in net cages from juveniles to market size with dry feed pellets as the main food source, although in some areas and for some species (e.g. Atlantic bluefin tuna) baitfish may continue to play a role. The fish species considered for offshore are those already of importance in coastal farms, e.g. salmon, sea trout, sea bream, sea bass, cobia and kingfish, mostly due to previous production experience and the existing markets for these species. The offshore production of some species, such as salmon, is questioned as they require calm and sheltered conditions, which could prevent this important economic species from expansion in offshore waters. Other less common coastal species, such as tuna, cod and halibut, may have greater potential in offshore conditions for various reasons, including environmental issues. Due to the rough weather conditions at offshore sites, new types of farm installations have been developed extending from net cages anchored to the seafloor at shallower sites, to diver-operated submerged cages anchored to the bottom, drifting net systems and cages moored in connection with wind and wave farms or abandoned offshore oil rigs. Due to their remote location, farms are expected to increase automatic operations with advanced remote technology to accommodate the size of the farms and the limitations in access due to weather conditions ( $80 \%$ accessibility, Table 1 ).

Integrated multi-trophic farming has been proposed for offshore farming for similar reasons as in coastal farming, including environmental sustainability (Troell et al. 2009). The environmental conditions for growing shellfish and macroalgae together with fish are present at offshore locations, with some added benefits such as lower pressure from infectious parasites (Buck \& Buchholz 2005, Michler-Cieluch \& Kodeih 2008). Natural food availability could limit shellfish production (Clausen \& Riisgård 1996) and low nutrient concentrations macroalgae production (Sanderson et al. 2008). The problems, including low-technology solutions and identification of high-value products are, however, the same or even exaggerated in offshore farming due to higher costs of investment and production compared to coastal farms (Troell et al. 2009).

\section{ENVIRONMENTAL CONDITIONS AT OFFSHORE SITES}

\section{Shelf research}

Fundamental biological and ecological knowledge from the shelf area, as identified for offshore farming, varies greatly. Some regions are well studied (e.g. the North and Mediterranean Seas), while other regions (e.g. Arctic and tropical regions) are poorly known, especially concerning the productivity and diversity of benthic habitats. Shelf studies are constrained by high operational costs for sampling in deep waters, and most information is available from sites selected for scientific or exploitation purposes, whereas monitoring of water column conditions and benthic habitats is largely absent. Lack of background information on environmental conditions may significantly hamper the expansion of offshore farming, particularly due to the high costs of pre-screening surveys of biological, chemical and physical oceanography at potential offshore sites. Lack of knowledge from benthic habitats is critical, as sediments are likely to become organically enriched by offshore farming. As the benthic fauna community structure and functionality controls the fate of settling organic matter (Valdemarsen et al. 2010), such information is essential to predict the assimilative capacity of benthic shelf systems. Furthermore, because the interaction between wild and cultured fish is an issue in offshore farming, knowledge on wild fish populations is important when planning offshore activities. Most information is available from intensive fishing areas, where siting of offshore farms probably should be avoided to minimize conflicts between user groups.

\section{Water column and fisheries in shelf areas}

Due to low nutrient concentrations, water quality is beneficial for farming at offshore sites compared with coastal areas, reducing the risk of phytoplankton blooms, including those of toxic species (Pelegri et al. 2006). However, some shelf locations (upwelling, eutrophic temperate and Arctic areas) are productive with relatively high nutrient concentrations, which could affect the water quality. Moreover, toxic algae blooms occur relatively frequently in offshore areas in the Baltic Sea (Mazur-Marzec \& Plinski 2009) and off the European Atlantic coast (Gypens et al. 2007), posing a risk to offshore production. Release of nutrients from fish farms may stimulate primary production when nutrients are limiting (Dalsgaard \& KrauseJensen 2006) and light is sufficient (Pelegri et al. 2006). Nitrogen limits primary production in temperate shelf areas during the summer, and release of nitrogen from fish farms (ammonium from excretion) during summer may stimulate temperate primary production. In the tropics, phosphorus is the most limiting nutrient and nitrogen is limiting seasonally (Fong et al. 2003), and nutrient addition experiments in water columns in shelf areas show stimulation of primary production (Debes et al. 2008). Furthermore, a shift in size distrib- 
ution of the phytoplankton from small to larger species was observed, affecting the transfer of carbon and nutrients in the trophic chain through grazing (McAndrew et al. 2007b). Dissolved organic nutrients leaching from feed pellets and faeces (Fernandez-Jover et al. 2007b) also stimulate the pelagic processes, including the microbial loop. This may increase bacterial activity and affect the trophic chain (Havskum et al. 2003), but modifications of the trophic chain under enrichment conditions are poorly elucidated. A single study near fish farms in the Mediterranean Sea, however, showed a rapid transfer of fixed carbon to higher trophic levels (Pitta et al. 2009), indicating cascadal effects in the water column upon nutrient additions.

Fisheries are important in the shelf area, although they are concentrated in certain areas of high productivity (Worm et al. 2003). There is a risk of conflict between users, and siting of offshore farms will be important to minimize potential conflicts. The direct interactions between wild fish and cultured species are not known and are difficult to predict due to limited information on offshore fish communities compared to coastal areas. The interactions between wild and cultured fish extend from enhanced production of wild fish in farm vicinities to transmission of diseases and parasites and genetic impacts on wild fish.

\section{Benthic shelf systems}

The benthic shelf environment receives less light compared to shallower coastal sites and, because of their depth, the light-dependent habitats (seagrass meadows and macroalgae beds) become less abundant. However, in the tropics light can penetrate 50 to $100 \mathrm{~m}$ and offshore farms may be placed over macroalgae beds, maerl communities or coral reefs. These ecosystems are highly sensitive to nutrient inputs and organic loading (Bongiorni et al. 2003, Holmer et al. 2003, Hall-Spencer et al. 2006) and are a risk in offshore locations. There are other non-photosynthetic benthic habitats, such as cold-water corals and sponges growing at depth, which are expected to be sensitive to organic matter loading (Bongiorni et al. 2003). The vast majority of benthic habitats in shelf areas are, however, dominated by bare sediments, ranging from fine-grained muddy sediments under weak currents to coarse-grained shell sand under strong currents (Gage 1996). These deep benthic communities (fauna and microbial) are generally carbon limited, controlled by low input of organic matter from the overlying water column (Gage 1996). The benthic fauna abundance and biomass, as well as microbial activity, are up to several orders of magnitude lower compared to coastal sediments (Wenzhofer \& Glud
2002). There is virtually no information available on the response of benthic shelf communities to organic enrichment. A certain capacity to consume (fauna) and decompose (microbial) organic matter can be expected, although it is important to take into account the high quality of organic matter settling from fish farms compared to allochthonous material. Fish farm waste is enriched in proteins and lipids, and even low sedimentation rates add relatively large amounts of labile organic matter to the benthic compartment (Holmer et al. 2007, Pusceddu et al. 2007). Where coastal sediments host a diverse benthic fauna community, some of which are tolerant to organic pollution, shelf fauna are adapted to low food conditions, oxic or oxidized sediments and are most likely less tolerant to organic enrichment (Lee et al. 2006, Kutti et al. 2007b). Such a benthic community may rapidly be wiped out by organic inputs from farms, with limited potential of reestablishment due to low recruitment and slow growth rates (Gage 1996). Low recruitment also affects the potential for regeneration of the sediments after fallowing. If no pollution-tolerant fauna are present to colonize the enriched sediments, the stimulatory effect of benthic fauna in regenerating sediments is less, increasing the duration of the recovery period (Macleod et al. 2007, Lin \& Bailey-Brock 2008). In contrast to the benthic fauna, the bacterial community structure and functionality in the sediments is far more cosmopolitan (Canfield et al. 1993), and the bacterial community may potentially respond to organic enrichment as observed in coastal sediments. Bacterial activity in marine sediments is controlled by the chemical properties of seawater, diffusion and advection processes in the sediments, benthic fauna activity and organic matter loading to the sediments (Thamdrup \& Canfield 1996). Upon organic enrichment, oxygen, which is the most efficient electron acceptor, is consumed first due to low solubility in the water column and low penetration into the sediments (Glud 2008). Oxygen depletion is possibly faster in shelf sediments due to low bioturbation and/or bioirrigation activity by the benthic fauna compared to coastal sediments. Iron and manganese reduction could, on the other hand, play a greater role due to higher pools of these compounds (Jensen et al. 2003), but their capacity as carbon oxidation agents is also controlled by the bioturbation and/or bioirrigation activities (Valdemarsen et al. 2009), and may thus be exhausted relatively quickly in shelf sediments. Ultimately, sulfate reduction takes over, stimulated by inputs of organic matter and high sulfate concentrations in seawater. Sulfate reduction is an important process in fish farm sediments, where it dominates the carbon oxidation process (Holmer \& Kristensen 1992). High sulfate reduction rates increase the risk of accumulation of sulfides displacing sensitive 
benthic fauna (Hargrave et al. 2008), which may be critical in shelf sediments, where the benthic fauna is adapted to oxidized conditions. Thus organic enrichment and the microbial response to this input pose a threat to the benthic fauna in shelf sediments.

\section{ENVIRONMENTAL ISSUES OF OFFSHORE MARICULTURE}

A range of environmental issues have been identified in coastal and off-coast farming over the past 2 decades (Table 2), whereas existing evidence on environmental impacts at offshore farms with full-scale production is limited (Table 3). The aim of this part of the review is to provide an overview of the environmental issues known from coastal and off-coast farms and to discuss the possible environmental issues with offshore farming from this existing knowledge. The issues are addressed by first considering the problems identified as the most severe in coastal and off-coast farms.

\section{Visual impact and ecological footprint}

Visual impact is of primary concern in coastal farming (Table 2), and is one of the main reasons for moving farms out to sea in the Mediterranean. This is, for instance, enforced by the Turkish government to avoid visual interaction with the coastal tourist industry (Ersan 2005). Farming offshore will relieve this longlasting conflict in the coastal zone.

The use of fish for feed is controversial and is considered one of the most important environmental issues in the predicted expansion of mariculture (Naylor \& Burke 2005, Naylor et al. 2009, Tacon \& Metian 2009), and is a major problem for expansion of offshore farming (Table 2; Duarte et al. 2009). Fish feed generates pressure on wild fish stocks, in particular due to the low efficiency in feeding carnivorous fish, which are the high volume species in marine fish farming (Naylor \& Burke 2005, Duarte et al. 2009). Integrated multitrophic aquaculture (IMTA) principles may release this pressure, but lack technological solutions. Culturing of

Table 2. Environmental impacts and change in ecosystem services of mariculture in coastal and off-coast locations and predictions for offshore locations. Impacts are listed by category as low (barely detectable), medium (enrichment/detectable) and severe (negative impact), and offshore predictions as lower, no change or higher impact compared to coastal/off-coast

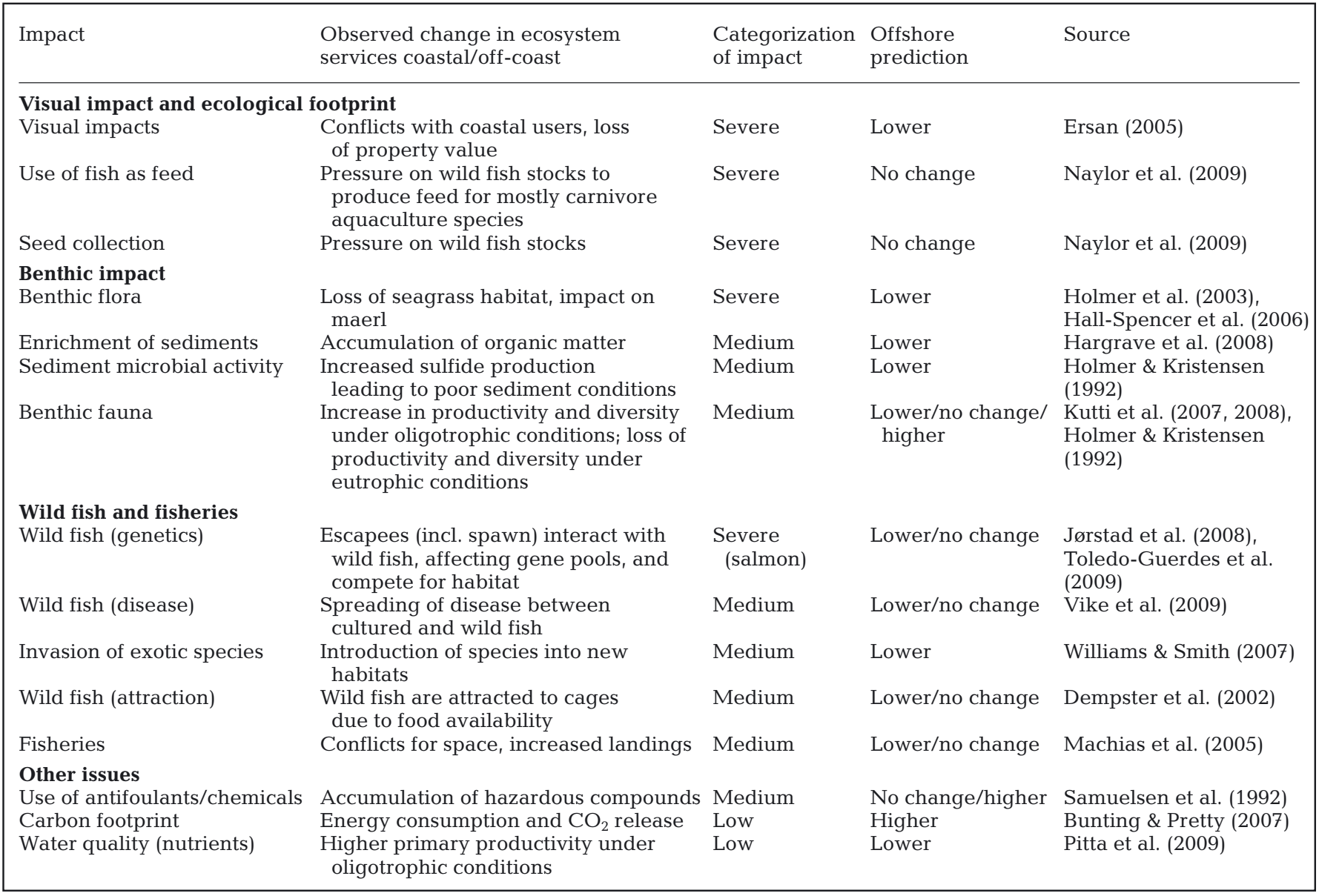




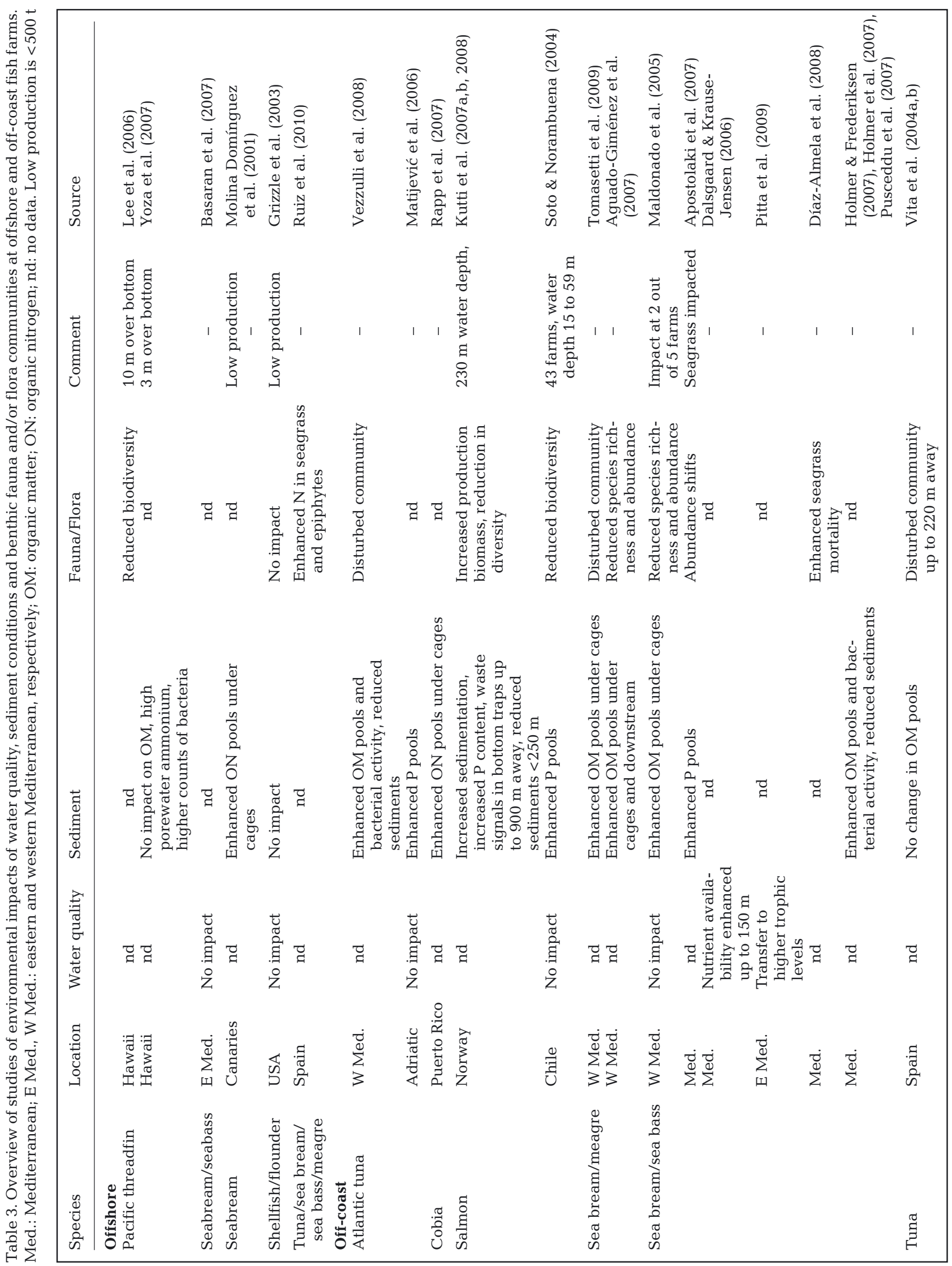


species at lower trophic levels, such as herbivorous fish and shellfish, could immediately benefit the ecological footprint, but it is constrained by low market demands (Duarte et al. 2009). In addition to feed, collection of wild larvae or juveniles for capture-based aquaculture (e.g. tuna farming) has major environmental implications, especially if the wild stocks are in danger of extinction (Naylor \& Burke 2005). With the expansion of the production capacity in offshore farming, this issue may become more severe, unless the production cycles are closed with larvae and juveniles obtained from brood stock (Duarte et al. 2009). Closed production cycles are likely to occur for an increasing number of species, although some species, including endangered species as Atlantic bluefin tuna, still pose major difficulties for the breeding industry.

\section{Benthic impacts}

Benthic impacts are of primary concern in mariculture (Table 2), in particular under eutrophic conditions where accumulation of organic matter in the sediments may result in anoxia and loss of secondary production and biodiversity (Hargrave et al. 2008). Studies at off-coast farms show less benthic impact compared to coastal farms due to larger dispersion of particulate waste products (Table 3). However, Kutti et al. (2007a) examined an off-coast farm located at $230 \mathrm{~m}$ water depth and found increased rates of sedimentation at distances up to $900 \mathrm{~m}$ away from the farm, suggesting that deep-water farms can induce enrichment of sediments over large areas. Interestingly, they found an increase in the benthic fauna biomass and diversity, suggesting a stimulation of the production in the benthic community (Kutti et al. 2007b, 2008). The farm was located relatively close to shore and could be considered a coastal farm with a low degree of exposure. Findings of enriched benthic communities have been, however, confirmed at other off-coast and offshore farms (Table 3). The enrichment may positively affect fauna density and increase fauna biomass, whereas the community structure is modified with greater incidence of pollution-tolerant species under the net cages (Table 3). Benthic impacts can thus be expected in off-coast and offshore farms, despite their location in deeper water and more exposed conditions. This is attributed to the rapid sinking rates of feed and faecal pellets, resulting in significant sedimentation in farm vicinities (Holmer et al. 2007, Pusceddu et al. 2007). Cromey et al. (2002) reported sinking rates of 8 to $16 \mathrm{~cm} \mathrm{~s}^{-1}$ for feed and faecal pellets ranging in diameter between 2 and $13 \mathrm{~mm}$. Calculations show that it takes between 2 to $4 \mathrm{~min}$ to sink to $20 \mathrm{~m}$, but only 10 to $20 \mathrm{~min}$ to sink to $100 \mathrm{~m}$, assuming that the sedimenta- tion pattern is the same in a deeper water column. Such fast sinking rates will, under low current speeds, allow sedimentation of particles in the immediate vicinity of the net cages, as found by Kutti et al. (2007a). Dispersion increases as current velocities increase, but large particles will, unless they disintegrate into smaller parts, sink and settle near the cages. Storm events during passage of low pressure systems or tropical storms can create turbulent waters and modify the settling of particles, in particular for cage systems located at the surface. However, as most weather events are seasonal, confined to winter or hurricane seasons of shorter duration, turbulence and strong currents may play a relatively minor role in the sedimentation of waste products over an annual cycle. Moreover, changes in water currents are often confined to the surface layers, leaving the deeper parts of the water column under calmer conditions and allowing fast sedimentation of large particles. Only in locations with permanent strong currents, e.g. areas influenced by tidal currents, can extensive dispersion of particles be expected. Under these conditions it is important to monitor connected sedimentation basins where waste products may accumulate as the current velocity decreases.

Yoza et al. (2007) found increased numbers of sulfate-reducing bacteria at an impacted offshore site, suggesting a stimulated microbial response to organic enrichment. Results from deep Norwegian off-coast farms (200 to $500 \mathrm{~m}$ ) indicate stimulated sulfate-reduction activity under net cages compared to control sites (T. Valdemarsen unpubl. data). A prolonged effect of organic enrichment on microbial activity and sulfide accumulation in deep sediments is suggested from fallowing studies at off-coast farms. The fallowing period was significantly longer compared to coastal farms (Macleod et al. 2006), and the enrichment of the sediments disappeared relatively fast, but the benthic fauna were slow to recover (Macleod et al. 2006). The slow recovery of the benthic fauna was attributed to low regeneration potential hampered by the absence of pollutant-tolerant species, which recolonize the impacted and possibly sulfidic sediments (Hargrave et al. 2008). As the benthic fauna in shelf areas are characterized by slow growth and low recolonization potential after natural events or trawling (Gage et al. 2005), this could be a major concern for fallowing practices in offshore farms.

\section{Interactions with wild fish and predators}

Fish farms are artificial structures in the sea and act as fish aggregation devices (Dempster \& Taquet 2004), and the loss of waste feed and nutrients increases the availability of food, attracting wild fish to the farms 
(Dempster et al. 2002, 2004, 2009, Fernandez-Jover et al. 2007a). Predatory fish and mammals have also been observed in farm surroundings predating on both the cultured and attracted fish (Nash et al. 2000, Sepulveda \& Oliva 2005). Furthermore, the input of particulate waste to the sediments attracts benthic fish and stimulates the productivity of benthic fauna and epifauna, providing food for benthic fish (Kutti et al. $2007 \mathrm{~b}$ ). Wild fish are attracted to shellfish farms, where they predate on the cultured shellfish and epifauna or search for food in the benthic communities established in shell debris under the farms (Dubois et al. 2007). Attraction of wild fish and predators is expected at offshore farms for the same reasons as in coastal farms, but the species most likely differ from coastal farms, reflecting offshore fish populations (Table 4). Due to the lack of general knowledge on offshore fish (e.g. feeding habits, population dynamics), their interactions with farms are difficult to predict. At coastal and off-coast sites, wild fish aggregate near all types of farms, but show great spatial and temporal variability modified by a range of factors such as farm management, local environmental conditions and seasonality in migration (Battin 2004). The aggregations can attain quite high abundance and biomass (many tonnes per farm), stimulated by the high quantity and quality of the waste feed (Dempster et al. 2009). The presence of wild fish may reduce the benthic impact due to their feeding (Vita et al. 2004a,b), but the farms can also act as ecological traps, misleading fish to inappropriate habitat selection or diverting migrating fish from migration routes, making them susceptible to capture and thereby increasing their mortality rates (Battin 2004).

A concern at offshore farms is the attraction of large predators, causing damage to nets during their hunt for prey. Damage of nets is an economic as well as ecological risk due to the release of farmed fish to the wild. On the Pacific coast of the USA and Canada, sea lions and harbor seals interact with coastal fish farms by predating upon salmonids inside the cages while damaging netting in the process (Nash et al. 2000). On the Atlantic coast, harbor seals and grey seals pose similar problems (Nash et al. 2000), and in Chile, negative interactions of sea lions with salmon farms have been described (Sepulveda \& Oliva 2005). Moving farms offshore could attract larger and more abundant predators to the farms, including species such as sharks and killer whales. If offshore net cages are attacked, there is a risk of releasing millions of cultured fish due to the large size of the farms. Escapees, cultured fish unintentionally released into the wild, are a major and increasing problem in mariculture (Naylor et al. 2005). Escapees may interbreed with wild conspecifics and reduce the genetic diversity of the local populations,

Table 4. Examples of interactions between wild fish and fish farms at coastal (CO) and off-coast (OFC) farms

\begin{tabular}{|c|c|c|c|c|}
\hline Species & Farm type & Location & Observation & Source \\
\hline Cod & OFC & Norway & Ecosystem effects of escaped cod & Uglem et al. (2008) \\
\hline \multirow[t]{8}{*}{ Salmon } & $\mathrm{CO} / \mathrm{OFC}$ & Chile & $\begin{array}{l}\text { Escapees low survival in native } \\
\text { ecosystems, increase in marine } \\
\text { birds in farming areas }\end{array}$ & Buschmann et al. (2006) \\
\hline & $\mathrm{CO}$ & British Colombia & $\begin{array}{l}\text { Mercury contamination of rockfish } \\
\text { present near fish farms }\end{array}$ & deBruyn et al. (2006) \\
\hline & Model & Norway & $\begin{array}{l}\text { Spawning of cultured cod affect } \\
\text { wild populations }\end{array}$ & Jørstad et al. (2008) \\
\hline & Model & British Colombia & $\begin{array}{l}\text { Infection of wild juvenile Pacific } \\
\text { salmon with parasitic sea louse }\end{array}$ & Krkosek et al. (2009) \\
\hline & OFC & US & Attraction of seals and sea lions to farms & Nash et al. (2000) \\
\hline & $\mathrm{CO} / \mathrm{OFC}$ & Chile & Attraction of sea lions to farms & Sepulveda \& Oliva (2005) \\
\hline & $\mathrm{CO}$ & Norway & Aggregation of saithe near farms & Uglem et al. (2009) \\
\hline & $\mathrm{CO} / \mathrm{OFC}$ & Chile & Attraction of sea lions to farms & Vilata et al. (2010) \\
\hline \multirow[t]{6}{*}{$\begin{array}{l}\text { Sea bream/ } \\
\text { sea bass }\end{array}$} & $\mathrm{OFC}$ & Spain & $\begin{array}{l}\text { Aggregation of wild fish in great } \\
\text { abundance and biomass near farms }\end{array}$ & Dempster et al. (2002) \\
\hline & $\mathrm{OFC}$ & Spain & $\begin{array}{l}\text { Aggregation of } 53 \text { different species } \\
\text { of wild fish near farms }\end{array}$ & Dempster et al. (2005) \\
\hline & $\mathrm{CO}$ & Greece & $\begin{array}{l}\text { Enhancement of local stocks due to } \\
\text { spawning in farms }\end{array}$ & Dimitriou et al. (2007) \\
\hline & $\mathrm{OFC}$ & Spain & $\begin{array}{l}\text { Change in growth of attracted fish } \\
\text { to cages }\end{array}$ & Fernandez-Jover et al. (2007a) \\
\hline & $\mathrm{OFC}$ & Spain & $\begin{array}{l}\text { No increase in parasite infections, } \\
\text { but new types of parasites in wild } \\
\text { fish near fish farms }\end{array}$ & Fernandez-Jover et al. (2010) \\
\hline & $\mathrm{OFC}$ & Spain & $\begin{array}{l}\text { Establishment of escaped fish in } \\
\text { native habitats }\end{array}$ & Toledo-Guedes (2009) \\
\hline Tuna & $\mathrm{OFC}$ & Italy & $\begin{array}{l}\text { Reduced benthic load due to consump- } \\
\text { tion of waste products by attracted fish }\end{array}$ & Vita et al. $(2004 a, b)$ \\
\hline
\end{tabular}


which is a major problem in the salmon industry (Cross et al. 2008). Escapees may also obstruct the natural habitats, interfering with the native species for breeding sites and food (Jacobsen \& Hansen 2001, Buschmann et al. 2006), and they increase the risk of transfer of disease and parasites to wild fish (Olivier 2002, Vike et al. 2009). A relatively new interaction is 'escape through spawning', as an increasing number of species are cultured until maturity, e.g. Atlantic cod (Jørstad et al. 2008) and sea bream (Dimitriou et al. 2007). In this way the cultured strains are released directly into the surroundings, where they can establish and compete with wild fish. Environmental impacts of escapees are well documented from salmon farming in Norway (Krkosek et al. 2007), whereas interactions for other species are less well known. Impacts of sea bream and sea bass escapees are assumed to be less compared to salmon due to more abundant native populations and lack of local adaptations of the stocks (Toledo-Guedes et al. 2009). Increased landings and reduced size of wild-caught sea bream and sea bass in intensive farming areas in the Mediterranean, however, suggest the presence of ecological interactions (Sánchez-Lamadrid 2004, Dimitriou et al. 2007). Similar interactions can be expected at offshore locations, which is their native habitat. The degradation of the wild strains of cultured species due to genetic interactions could be avoided by using sterile or triploid fish, and although these methods are available, many difficulties and uncertainties remain to be solved for most species. Only a few successful examples have been provided so far (Cross et al. 2008).

Similar to coastal farms, there is a risk of spreading diseases between farmed and wild fish and vice versa, and several scenarios can be predicted for offshore farms (Table 2). Due to the increasing size of the farms, the risk of transmission of disease from cultured to wild fish is higher compared to smaller farms, but on the other hand, the move to offshore locations could minimize the incidences of diseases due to better water quality. The risk of spreading parasites is expected to decline due to the physical removal from the intermediate hosts, although farmed fish in net cages may become infested by parasites from wild fish and in turn become point sources for parasites (Nowak 2007). The risk is high, if offshore farms are placed near major migration routes or in areas with intensive fishing. Some offshore farms may still be relatively close, e.g. within a few kilometers, to the coastal areas and similar risks of direct and indirect interactions with wild fish populations are possible. Only if the farms are located in open seas, e.g. tens to hundreds of kilometers away, can interactions with coastal populations be reduced.
Mariculture has led to introductions of exotic species through transportation of cultured species and escapees, with severe ecological implications (Table 2; Williams \& Smith 2007). One example of an introduced species with a major impact is the widespread invasion of Pacific oysters along the Northern European coasts, where it outcompetes native species (Markert et al. 2010). Locating farms further offshore may both increase the risk of introductions due to larger dispersal upon escape, but could also reduce the pressure on the environment due to lack of suitable habitats for the exotic species. Climate change, resulting in higher winter temperatures, allows production of species new to temperate conditions and farming in areas previously unexplored for mariculture (e.g. in Arctic areas), thus increasing the risk of exotic introductions in temperate and Arctic areas.

\section{Use of antifoulants/chemicals}

Various chemicals, including antifoulants, are used in mariculture and accumulate in the benthic organisms and sediments below the net cages (Costello et al. 2001, Dean et al. 2007). The use of medicines for treatment of cultured fish, such as antibiotics, poses an environmental threat in the form of transmission to wild organisms and development of bacterial resistance in nature (Samuelsen et al. 1992). As the use of these environmental hazards and medicines is expected to decrease in offshore farming due to better water quality and less growth of biofouling combined with increased dispersal, the environmental threat is most likely lower (Table 2). The lack of knowledge on the sensitivity of benthic habitats on the shelf to environmental hazards and medicines is, however, a critical uncertainty and it is difficult to predict the environmental impacts of offshore farming. Experimental research should be applied to investigate possible impacts of farm-derived environmental hazards on benthic habitats.

\section{Carbon footprint}

Mariculture has a high carbon footprint when compared to low-energy freshwater farming, but a low footprint compared to the production of livestock, as livestock emit methane, contributing to global warming (Bunting \& Pretty 2007). The carbon footprint is predicted to increase as fish farms move offshore due to increased energy use for transportation of materials, feed and cultured fish (Table 2). Optimizing energy use at offshore farms with renewable energy sources could compensate for some of the increased energy use. 


\section{Water quality}

Finally, the last environmental issue to address in this review is water quality, which is considered one of the less severe impacts (Sara 2007). The water quality around coastal fish farms is affected by the release of dissolved and particulate inorganic and organic nutrients, but, due to rapid dispersal, only limited impacts have been documented (Table 3). Assessments of water quality are, however, often confounded by the methods used, addressing static parameters such as concentrations of nutrients and chlorophyll a rather than productivity and nutrient uptake (Dalsgaard \& Krause-Jensen 2006, Pitta et al. 2009). However, Machias et al. (2005) showed that the primary production increased in farm surroundings under oligotrophic conditions in the Mediterranean Sea, eventually stimulating productivity at higher trophic levels (e.g. fisheries). By moving the farms further offshore to exposed conditions, the dispersal of nutrients is expected to increase, minimizing the pressure on the environment (Table 2). None of the available studies at off-coast and offshore farms have detected significant nutrient enrichment or effects on the water column (Table 3), suggesting a rapid dispersal of dissolved compounds or a rapid transfer of waste products to higher trophic levels (Pitta et al. 2009).

\section{ENVIRONMENTAL RESEARCH NEEDS}

As the shelf area is underexplored, particularly with respect to the impacts of nutrient and organic enrichment, there are substantial research needs related to expansion of offshore mariculture. The sensitivity of the benthic habitats to organic enrichment is critical, as the sediments are likely to receive a higher load. Studies should address the assimilative capacity of deep sediments at a range of sedimentation regimes, varying the quality and quantity of the settling organic matter, reflecting possible sedimentation scenarios along an exposure gradient. Population dynamics of the benthic fauna, including recruitment and tolerance to organic pollution, are largely unknown, may affect the extent of decomposition of organic matter in the sediments and are critical for the fallowing process. Fallowing is used in coastal aquaculture with good results, where the regeneration of the benthic communities is stimulated by rapid recolonization by benthic fauna. This scenario is likely much different in deep sediments, which are characterized by much slower growth and reproduction of benthic fauna and absence of pollutant-tolerant species. In addition, the distribution of sensitive benthic communities (sponge, maerl and corals) and their responses to organic enrichment are largely unknown from the shelf area. Detailed mapping of sensitive habitats and designation of farming areas avoiding sensitive habitats would be a strong tool for siting new offshore farms. Hydrodynamics and physical oceanography play a major role in the dispersion of waste products, but are largely unknown at farm scales, prohibiting predictive modeling of farm impacts as well as other issues for management (e.g. risk analysis of net failure). The lack of knowledge on several aspects of wild fish in offshore locations, such as population dynamics, attraction to fish aggregating devices, consumption of waste products and susceptibility to disease and environmental hazards, pose a risk for the development of offshore farming.

New production technologies, such as the use of submerged cages or drifting farms, could modify the environmental impacts, and should be subject to further studies. Where submerged farms may increase the sedimentation compared to floating cages, drifting systems could reduce the overall loading of waste products at a local level, but could spread the waste products over larger areas. Farms located together with other types of marine installations (wind and/or wave farms) are not known from coastal aquaculture and the environmental interactions need to be explored. IMTA principles are well established in tropical fish farming, but are still in their infancy in temperate coastal aquaculture, and environmental impacts remain largely unexplored. IMTA may reduce the environmental impacts directly by uptake of dissolved nutrients by primary producers (e.g. macroalgae) and of particulate nutrients by suspension feeders (e.g. mussels), and through harvesting remove the nutrients from the location. Reuse of these extractive organisms for fish feed is an indirect reduction of environmental pressure through alleviation of the pressure on wild stocks exploited for fish feed (Duarte et al. 2009).

There is an urgent need for a consensus on environmental monitoring of mariculture worldwide to ensure that sustainable development occurs at offshore sites. Several of the major producer countries, such as Norway and Scotland, apply fairly comprehensive monitoring programs (Ervik et al. 1997), whereas monitoring is more variable elsewhere. Dissemination of the knowledge from well-established monitoring programs at a global level could promote consensus. Coastal monitoring programs, however, have to be adapted to offshore conditions, taking into account both the deeper water column and the shelf sediments. The development of remote sensing equipment (e.g. loggers, surveillance cameras) and monitoring equipment for deep waters (e.g. remotely operated vehicles) is required to facilitate research and monitoring under offshore conditions. 


\section{CONCLUSIONS}

The key question that remains is if mariculture will expand into offshore locations. For environmental reasons there are several benefits in moving farms from coastal to offshore locations. Increased dispersal of dissolved and particulate nutrients reduces the intensity of environmental interactions at farming sites and possibly increases the assimilative capacity of the ecosystem. The physical movement of the farms away from the coastal zone reduces the interaction with coastal flora and fauna and minimizes the risk of diseases and parasite infections. Environmental issues can be further reduced if offshore farms are placed at sites away from sensitive benthic habitats (e.g. biological hotspots) and major fish and mammal migration routes to minimize the interaction between wild and cultured fish. Locating farms in areas of already existing offshore installations could be an advantage for technological and legal issues. The lack of scientific knowledge on offshore fish, mammal and benthic communities is problematic for the development of offshore mariculture, as cautionary principles have to be applied until sufficient documentation is available. Bottlenecks of sustainable feeds and use of wild stocks remain a challenge to offshore production as well as aquaculture development in general. Even with substantial scientific efforts into environmental issues, other questions, such as legal issues, technological challenges and market conditions, are likely to become critical drivers of the blue revolution at offshore locations.

Acknowledgement. I am grateful to T. Dempster and 5 anonymous reviewers for comments to an earlier version of this review.

\section{LITERATURE CITED}

Aguado-Giménez F, Marin A, Montoya S, Marín-Guirao L, Piedecausa A, García-García B (2007) Comparison between some procedures for monitoring offshore cage culture in western Mediterranean Sea: sampling methods and impact indicators in soft substrata. Aquaculture 271: $357-370$

Apostolaki ET, Tsagaraki T, Tsapaki M, Karakassis I (2007) Fish farming impact on sediments and macrofauna associated with seagrass meadows in the Mediterranean. Estuar Coast Shelf Sci 75:408-416

Basaran AK, Aksu M, Egemen O (2007) Monitoring the impacts of the offshore cage fish farm on water quality located in Ildir Bay (Izmir-Aegean Sea). J Agric Sci 13: 22-28

Battin J (2004) When good animals love bad habits: ecological traps and the conservation of animal populations. Conserv Biol 18:1482-1491

Bongiorni L, Shafir S, Angel D, Rinkevich B (2003) Survival, growth and gonad development of two hermatypic corals subjected to in situ fish-farm nutrient enrichment. Mar Ecol Prog Ser 253:137-144

Buck BH, Buchholz CM (2005) Response of offshore cultivated Laminaria saccharina to hydrodynamic forcing in the North Sea. Aquaculture 250:674-691

Bunting S, Pretty J (2007) Aquaculture development and global carbon budgets: emissions, sequestration and managment options. Centre for Environment and Society Occasional Paper 2007-1. University of Essex, Colchester

Buschmann $\mathrm{AH}$, Riquelme VA, Hernandez-Gonzalez $\mathrm{MC}$, Varela D and others (2006) A review of the impacts of salmonid farming on marine coastal ecosystems in the southeast Pacific. ICES J Mar Sci 63:1338-1345

> Canfield DE, Thamdrup B, Hansen JW (1993) The anaerobic degradation of organic matter in Danish coastal sediments: iron reduction, manganese reduction, and sulfate reduction. Geochim Cosmochim Acta 57:3867-3883

> Clausen I, Riisgård HU (1996) Growth, filtration and respiration in the mussel Mytilus edulis: no evidence for physiological regulation of the filter-pump to nutritional needs. Mar Ecol Prog Ser 141:37-45

Costello MJ, Grant A, Davies IM, Cecchini S, Papoutsoglou S, Quigley D, Saroglia M (2001) The control of chemicals used in aquaculture in Europe. J Appl Ichthyol 17: $173-180$

Cromey CJ, Nickell TD, Black KD (2002) DEPOMOD: modelling the deposition and biological effects of waste solids from marine cage farms. Aquaculture 214:211-239

Cross T, Burnell G, Coughlan S, Culloty S, Dillance E, McGinnity P, Rogan E (2008) Detrimental genetic effects of interactions between reared strains and wild populations of marine and anadromous fish and invertebrate species. In: Holmer M, Black K, Duarte CM, Marbà N, Karakassis I (eds) Aquaculture in the ecosystem. Springer, Dordrecht, p 117-154

Dalsgaard T, Krause-Jensen D (2006) Monitoring nutrient release from fish farms with macroalgal and phytoplankton bioassays. Aquaculture 256:302-310

> Dean RJ, Shimmield TM, Black KD (2007) Copper, zinc and cadmium in marine cage fish farm sediments: an extensive survey. Environ Pollut 145:84-95

Debes H, Gaard E, Hansen B (2008) Primary production on the Faroe shelf: temporal variability and environmental influences. J Mar Syst 74:686-697

> deBruyn AMH, Trudel M, Eyding N, Harding J and others (2006) Ecosystemic effects of salmon farming increase mercury contamination in wild fish. Environ Sci Technol 40:3489-3493

Dempster T, Taquet M (2004) Fish aggregation device (FAD) research: gaps in current knowledge and future directions for ecological studies. Rev Fish Biol Fish 14:21-42

> Dempster T, Sanchez-Jerez P, Bayle-Sempere JT, GiménezCasalduero F, Valle C (2002) Attraction of wild fish to seacage fish farms in the south-western Mediterranean Sea: spatial and short-term temporal variability. Mar Ecol Prog Ser 242:237-252

> Dempster T, Sanchez-Jerez P, Bayle-Sempere J, Kingsford M (2004) Extensive aggregations of wild fish at coastal seacage fish farms. Hydrobiologia 525:245-248

Dempster T, Fernandez-Jover D, Sanchez-Jerez P, Tuya F, Bayle-Sempere J, Boyra A, Haroun RJ (2005) Vertical variability of wild fish assemblages around sea-cage fish farms: implications for management. Mar Ecol Prog Ser 304:15-29

> Dempster T, Uglem I, Sanchez-Jerez P, Fernandez-Jover D, Bayle-Sempere J, Nilsen R, Bjorn PA (2009) Coastal salmon farms attract large and persistent aggregations of 
wild fish: an ecosystem effect. Mar Ecol Prog Ser 385:1-14 Díaz-Almela E, Marbà N, Álvarez E, Santiago R and others (2008) Benthic input rates predict seagrass (Posidonia oceanica) fish farm-induced decline. Mar Pollut Bull 56: 1332-1342

- Dimitriou E, Katselis G, Moutopoulos DK, Akovitiotis C, Koutsikopoulos C (2007) Possible influence of reared gilthead sea bream (Sparus aurata, L.) on wild stocks in the area of the Messolonghi lagoon (Ionian Sea, Greece). Aquac Res 38:398-408

> Duarte CM, Holmer M, Olsen Y, Soto D, Marbà N, Guiu J, Black K, Karakassis I (2009) Will the oceans help feed humanity? Bioscience 59:967-976

> Dubois S, Marin-Leal JC, Ropert M, Lefebvre S (2007) Effects of oyster farming on macrofaunal assemblages associated with Lanice conchilega tubeworm populations: a trophic analysis using natural stable isotopes. Aquaculture 271: 336-349

Ersan O (2005) National Aquaculture Sector overview. Turkey. FAO Fisheries and Aquaculture Department, Rome

> Ervik A, Hansen PK, Aure J, Stigebrandt A, Johannessen P, Jahnsen $T$ (1997) Regulating the local environmental impact of intensive marine fish farming. I. The concept of the MOM system (modelling-ongrowing fish farms-monitoring). Aquaculture 158:85-94

Fernandez-Jover D, Jimenez JAL, Sanchez-Jerez P, BayleSempere J, Casalduero FG, Lopez FJM, Dempster T (2007a) Changes in body condition and fatty acid composition of wild Mediterranean horse mackerel (Trachurus mediterraneus, Steindachner, 1868) associated to sea cage fish farms. Mar Environ Res 63:1-18

> Fernandez-Jover D, Sanchez-Jerez P, Bayle-Sempere J, Carratala A, Leon VM (2007b) Addition of dissolved nitrogen and dissolved organic carbon from wild fish faeces and food around Mediterranean fish farms: implications for waste-dispersal models. J Exp Mar Biol Ecol 340:160-168

> Fernandez-Jover D, Faliex E, Sanchez-Jerez P, Sasal P, BayleSempere JT (2010) Coastal fish farming does not affect the total parasite communities of wild fish in SW Mediterranean. Aquaculture 300:10-16

> Fong P, Boyer KE, Kamer K, Boyle KA (2003) Influence of initial tissue nutrient status of tropical marine algae on response to nitrogen and phosphorus additions. Mar Ecol Prog Ser 262:111-123

> Gage JD (1996) Why are there so many species in deep-sea sediments? J Exp Mar Biol Ecol 200:257-286

Gage JD, Roberts JM, Hartley JR, Humphery JD (2005) Potential impacts of deep-sea trawling on the benthic ecosystem along the Northern European continental margin: a review. Am Fish Soc Symp 41:503-517

Glud RN (2008) Oxygen dynamics of marine sediments. Mar Biol Res 4:243-289

Grizzle RE, Ward LG, Langan R, Schnaittacher GM, Dijkstra JA, Adams JR (2003) Environmental monitoring at an open ocean aquaculture site in the Gulf of Maine: results for 1997-2000. In: Bridger CJ, Costa Pierce BA (eds) Open ocean aquaculture: from research to commercial reality. World Aquaculture Society, Baton Rouge, LA, p 105-117

Gypens N, Lacroix G, Lancelot C (2007) Causes of variability in diatom and Phaeocystis blooms in Belgian coastal waters between 1989 and 2003: a model study. J Sea Res 57:19-35

Hall-Spencer J, White N, Gillespie E, Gillham K, Foggo A (2006) Impact of fish farms on maerl beds in strongly tidal areas. Mar Ecol Prog Ser 326:1-9

> Hargrave BT, Holmer M, Newcombe CP (2008) Towards a classification of organic enrichment in marine sediments based on biogeochemical indicators. Mar Pollut Bull 56: $810-824$

Havskum H, Thingstad TF, Scharek R, Peters F and others (2003) Silicate and labile DOC interfere in structuring the microbial food web via algal-bacterial competition for mineral nutrients: results of a mesocosm experiment. Limnol Oceanogr 48:129-140

Holmer M, Frederiksen MS (2007) Stimulation of sulfate reduction rates in Mediterranean fish farm sediments inhabited by the seagrass Posidonia oceanica. Biogeochemistry 85:169-184

Holmer M, Kristensen E (1992) Impact of marine fish cage farming on metabolism and sulfate reduction of underlying sediments. Mar Ecol Prog Ser 80:191-201

Holmer M, Perez M, Duarte CM (2003) Benthic primary producers: A neglected environmental problem in Mediterranean maricultures? Mar Pollut Bull 46:1372-1376

> Holmer M, Marba N, Díaz-Almela E, Duarte CM, Tsapakis M, Danovaro R (2007) Sedimentation of organic matter from fish farms in oligotrophic Mediterranean assessed through bulk and stable isotope $\left(\delta^{13} \mathrm{C}\right.$ and $\left.\delta^{15} \mathrm{~N}\right)$ analyses. Aquaculture 262:268-280

> Jacobsen JA, Hansen LP (2001) Feeding habits of wild and escaped farmed Atlantic salmon, Salmo salar L., in the Northeast Atlantic. ICES J Mar Sci 58:916-933

Jensen MM, Thamdrup B, Rysgaard S, Holmer M, Fossing H (2003) Rates and regulation of microbial iron reduction in sediments of the Baltic-North Sea transition. Biogeochemistry 65:295-317

> Jørstad K, van der Meeren T, Paulsen O, Thomsen T, Thorsen A, Svåsand T (2008) 'Escapes' of eggs from farmed cod spawning in net pens: recruitment to wild stocks. Rev Fish Sci 16:285-295

Krkosek M, Ford JS, Morton A, Lele S, Myers RA, Lewis MA (2007) Declining wild salmon populations in relation to parasites from farm salmon. Science 318:1772-1775

Krkosek M, Morton A, Volpe JP, Lewis MA (2009) Sea lice and salmon population dynamics: effects of exposure time for migratory fish. Proc R Soc Lond B 276:2819-2828

> Kutti T, Ervik A, Hansen PK (2007a) Effects of organic effluents from a salmon farm on a fjord system. I. Vertical export and dispersal processes. Aquaculture 262:367-381

Kutti T, Hansen PK, Ervik A, Hoisaeter T, Johannessen P (2007b) Effects of organic effluents from a salmon farm on a fjord system. II. Temporal and spatial patterns in infauna community composition. Aquaculture 262:355-366

Kutti T, Ervik A, Hoisaeter T (2008) Effects of organic effluents from a salmon farm on a fjord system. III. Linking deposition rates of organic matter and benthic productivity. Aquaculture 282:47-53

Lee HW, Bailey-Brock JH, McGurr MM (2006) Temporal changes in the polychaete infaunal community surrounding a Hawaiian mariculture operation. Mar Ecol Prog Ser 307:175-185

Lin DT, Bailey-Brock JH (2008) Partial recovery of infaunal communities during a fallow period at an open-ocean aquaculture. Mar Ecol Prog Ser 371:65-72

Machias A, Karakassis I, Giannoulaki M, Papadopoulou KN, Smith CJ, Somarakis S (2005) Response of demersal fish communities to the presence of fish farms. Mar Ecol Prog Ser 288:241-250

> Macleod CK, Moltschaniwskyj NA, Crawford CM (2006) Evaluation of short-term fallowing as a strategy for the management of recurring organic enrichment under salmon cages. Mar Pollut Bull 52:1458-1466

> Macleod CK, Moltschaniwskyj NA, Crawford CM, Forbes SE (2007) Biological recovery from organic enrichment: some 
systems cope better than others. Mar Ecol Prog Ser 342: 41-53

Maldonado M, Carmona MC, Echeverria Y, Riesgo A (2005) The environmental impact of Mediterranean cage fish farms at semi-exposed locations: Does it need a reassessment? Helgol Mar Res 59:121-135

> Markert A, Wehrmann A, Kroncke I (2010) Recently established Crassostrea-reefs versus native Mytilus-beds: differences in ecosystem engineering affects the macrofaunal communities (Wadden Sea of Lower Saxony, southern German Bight). Biol Invasions 12:15-32

Matijević S, Kušpilić G, Barić A (2006) Impact of a fish farm on physical and chemical properties of sediment and water column in the middle Adriatic Sea. Fresenius Environ Bull 15:1058-1063

Mazur-Marzec H, Plinski M (2009) Do toxic cyanobacteria blooms pose a threat to the Baltic ecosystem? Oceanologia 51:293-319

McAndrew PM, Bjorkman KM, Church MJ, Morris PJ, Jachowski N, Williams PJL, Karl DM (2007) Metabolic response of oligotrophic plankton communities to deep water nutrient enrichment. Mar Ecol Prog Ser 332:63-75

> Michler-Cieluch T, Kodeih S (2008) Mussel and seaweed cultivation in offshore wind farms: an opinion survey. Coast Manage 36:392-411

Molina Domínguez L, López Calero G, Vergara Martín JM, Robaina Robaina L (2001) A comparative study of sediments under a marine cage farm at Gran Canaria Island (Spain). Preliminary results. Aquaculture 192:225-231

Nash CE, Iwamoto RN, Mahnken CVW (2000) Aquaculture risk management and marine mammal interactions in the Pacific Northwest. Aquaculture 183:307-323

Naylor R, Burke M (2005) Aquaculture and ocean resources: raising tigers of the sea. Annu Rev Environ Resour 30: 185-218

Naylor R, Hindar K, Fleming IA, Goldburg R and others (2005) Fugitive salmon: assessing the risks of escaped fish from net-pen aquaculture. Bioscience 55:427-437

Naylor RL, Hardy RW, Bureau DP, Chiu A and others (2009) Feeding aquaculture in an era of finite resources. Proc Natl Acad Sci USA 106:15103-15110

Nowak BF (2007) Parasitic diseases in marine cage culture: An example of experimental evolution of parasites? Int J Parasitol 37:581-588

Olivier G (2002) Disease interactions between wild and cultured fish: perspectives from the American Northeast (Atlantic Provinces). Bull Eur Assoc Fish Pathol 22: 103-109

Pelegri JL, Marrero-Diaz A, Ratsimandresy AW (2006) Nutrient irrigation of the North Atlantic. Prog Oceanogr 70:366-406

Pitta P, Tsapakis M, Apostolaki ET, Tsagaraki T, Holmer M, Karakassis I (2009) 'Ghost nutrients' from fish farms are transferred up the food web by phytoplankton grazers. Mar Ecol Prog Ser 374:1-6

Pusceddu A, Fraschetti S, Mirto S, Holmer M, Danovaro R (2007) Effect of intensive mariculture on sediment biochemistry. Ecol Appl 17:1366-1378

Rapp P, Ramirez WR, Rivera JA, Carlo M, Luciano R (2007) Measurement of organic loading under an open-ocean aquaculture cage, using sediment traps on the bottom. J Appl Ichthyol 23:661-667

Ruiz JM, Marco-Méndez C, Sánchez-Lizaro JL (2010) Remote influence of off-shore fish farm waste on Mediterranean seagrass (Posidonia oceanica) meadows. Mar Environ Res 69:118-126

Samuelsen OB, Torsvik V, Ervik A (1992) Long-range changes in oxytetracycline concentration and bacterial resistance towards oxytetracycline in a fish farm sediment after medication. Sci Total Environ 114:25-36

> Sánchez-Lamadrid A (2004) Effectiveness of releasing gilthead sea bream (Sparus aurata, L.) for stock enhancement in the bay of Cádiz. Aquaculture 231:135-148

Sanderson JC, Cromey CJ, Dring MJ, Kelly MS (2008) Distribution of nutrients for seaweed cultivation around salmon cages at farm sites in north-west Scotland. Aquaculture 278:60-68

> Sara G (2007) Aquaculture effects on some physical and chemical properties of the water column: a meta-analysis. Chem Ecol 23:251-262

> Sepulveda M, Oliva D (2005) Interactions between South American sea lions Otaria flavescens (Shaw) and salmon farms in southern Chile. Aquac Res 36:1062-1068

Soto D, Norambuena F (2004) Evaluating salmon farming nutrient input effects in southern Chile inland seas: a large scale mensurative experiment. J Appl Ichthyol 20:1-9

Tacon AGJ, Metian M (2009) Fishing for feed or fishing for food: increasing global competition for small pelagic forage fish. Ambio 38:294-302

Thamdrup B, Canfield DE (1996) Pathways of carbon oxidation in continental margin sediments off central Chile. Limnol Oceanogr 41:1629-1650

Toledo-Guedes K, Sánchez-Jerez P, González-Lorenzo G, Hernández AB (2009) Detecting the degree of establishment of a non-indigenous species in coastal ecosystems: sea bass Dicentrarchus labrax escapes from sea cages in Canary Islands (Northeastern Central Atlantic). Hydrobiologia 623:203-212

Tomassetti P, Persia E, Mercatali I, Vani D, Marussso V, Porrello S (2009) Effects of mariculture on macrobenthic assemblages in a western mediterranean site. Mar Poll Bull 58:533-541

Troell M, Joyce A, Chopin T, Neori A, Buschmann AH, Fang JG (2009) Ecological engineering in aquaculture: potential for integrated multi-trophic aquaculture (IMTA) in marine offshore systems. Aquaculture 297:1-9

Uglem I, Bjorn OA, Dale T, Kerwath S and others (2008) Movements and spatiotemporal distribution of escaped farmed and local wild Atlantic cod (Gadus morhua L.). Aquac Res 39:158-170

Uglem I, Dempster T, Bjørn PA, Sanchez-Jerez P, Økland F (2009) High connectivity of salmon farms revealed by aggregation, residence and repeated movements of wild fish among farms. Mar Ecol Prog Ser 384:251-260

> Valdemarsen T, Kristensen E, Holmer M (2009) Metabolic threshold and sulfide-buffering in diffusion controlled marine sediments impacted by continuous organic enrichment. Biogeochemistry 95:335-353

Valdemarsen T, Kristensen E, Holmer M (2010) Sulfur, carbon, and nitrogen cycling in faunated marine sediments impacted by repeated organic enrichment. Mar Ecol Prog Ser 400:37-53

Vezzulli L, Moreno M, Marin V, Pezzati E, Bartoli M, Fabiano M (2008) Organic waste impact of capture-based Atlantic bluefin tuna aquaculture at an exposed site in the Mediterranean Sea. Estuar Coast Shelf Sci 78:369-384

Vike S, Nylund S, Nylund A (2009) ISA virus in Chile: evidence of vertical transmission. Arch Virol 154:1-8

Vilata J, Oliva O, Sepulveda M (2010) The predation of farmed salmon by South American sea lions (Otaria flavescens) in southern Chile. ICES J Mar Sci 67:475-482

Vita R, Marin A, Jimenez-Brinquis B, Cesar A, Marin-Guirao L, Borredat M (2004a) Aquaculture of bluefin tuna in the Mediterranean: evaluation of organic particulate wastes. 
Aquac Res 35:1384-1387

- Vita R, Marin A, Madrid JA, Jimenez-Brinquis B, Cesar A, Marin-Guirao L (2004b) Effects of wild fishes on waste exportation from a Mediterranean fish farm. Mar Ecol Prog Ser 277:253-261

Wenzhofer F, Glud RN (2002) Benthic carbon mineralization in the Atlantic: a synthesis based on in situ data from the last decade. Deep-Sea Res I 49:1255-1279

Williams SL, Smith JE (2007) A global review of the distribu-

Editorial responsibility: Tim Dempster,

Trondheim, Norway tion, taxonomy, and impacts of introduced seaweeds. Annu Rev Ecol Evol Syst 38:327-359

Worm B, Lotze HK, Myers RA (2003) Predator diversity hotspots in the blue ocean. Proc Natl Acad Sci USA 100: 9884-9888

Yoza BA, Harada RM, Nihous GC, Li QX, Masutani SM (2007) Impact of mariculture on microbial diversity in sediments near open ocean farming of Polydactylus sexfilisi Ecol Indic 7:108-122

Submitted: February 25, 2010; Accepted: July 11, 2010

Proofs received from author(s): July 24, 2010 